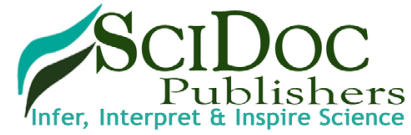

\section{Nutritional Characteristics of Maize-based Complementary Food Enriched with Fermented and Germinated Moringa Oleifera Seed Flour}

\author{
Research Article
}

Adeoti $\mathrm{OA}^{1,2^{*}}$, Osundahunsi $\mathrm{OF}^{1}$

${ }^{1}$ Department of Food Science and Technology, The Oke-Ogun Polytechnic, Saki Oyo State, Nigeria.

${ }^{2}$ Department of Food Science and Technology, The Federal University of Technology, Akure, Nigeria.

\title{
Abstract
}

Malnutrition of varying degrees has been associated with feeding infants with unwholesome and poor quality weaning foods. Therefore, the nutritional characteristics of maize-based complementary food enriched with fermented and germinated Moringa oleifera seed flour was investigated. The Moringa oleifera seeds were fermented and germinated using standard processing methods while the maize grains were fermented for the production of "ogi" flour. The proximate, antinutritional, mineral and functional properties of the formulated complementary food were determined. The results of the proximate composition of the diet showed that crude protein content of the complementary diets differed significantly $(\mathrm{p}<0.05)$ and the value ranged from 15.27 to $17.00 \%$ while the energy value ranged from 386.28 to $395.01 \mathrm{kcal}$. Phytate content of the sample ranged from 0.09 to $0.36 \mathrm{mg} / \mathrm{g}$ and the trypsin inhibitor value was 0.05 to $2.30 \mathrm{tiu} / \mathrm{mg}$. The predominant mineral elements are sodium and phosphorus whose values ranged from 58.60 to $67.85 \mathrm{mg} / 100 \mathrm{~g}$ and 57.58 to $68.58 \mathrm{mg} / 100 \mathrm{~g}$ respectively. Other mineral elements found in least amount are copper and manganese and the values ranged from 12.46 to $25.38 \mathrm{mg} / 100 \mathrm{~g}$ and 0.76 to $0.94 \mathrm{mg} / 100 \mathrm{~g}$ respectively. The loosed and packed bulk densities of the diet ranged from 0.54 to $0.57 \mathrm{~g} / \mathrm{ml}$ and 0.62 to $0.72 \mathrm{~g} / \mathrm{ml}$ while the water and oil absorption capacities of the samples were 179.00 to $194.00 \%$ and 140.00 to $150.00 \%$ respectively. The study established that fermented-ogi moringa seed flour was more nutritious in terms of the nutrient composition than the raw-ogi moringa seed and germinated-ogi moringa seed flours and it also compared favorably with commercial diet.

Keywords: Complementary Food; Fermented; Germinated; Moringa Oleifera; Nutrient.

\section{Introduction}

Complementary foods play a vital role on child growth and development since it complements for both nutritional and developmental needs of the infant when breast milk alone is no longer sufficient [62]. Good quality weaning food must have high nutrient density, bulk density, low viscosity, appropriate texture along with high energy, protein, micronutrient contents and consistency that allows easy consumption [17]. Several studies have reported that most of the complementary foods consumed by the infants in many parts of world are deficient in essential macronutrients and micronutrients leading to malnutrition, which is one of the serious public health problems in developing countries $[15,64$, 44]. Most lethal forms of malnutrition known as protein energy malnutrition generally occurs during the crucial transitional phase when children are weaned from liquid (breast milk) to semi-solid or fully adult (family) foods. In view of this nutritional problem, several strategies have been used to formulate weaning food through a combination of locally available food materials that complement each other in such a way as to create a new pattern of amino acids that provide the recommended daily allowance for infants [41].

Ogi is an acid-fermented cereal gruel or porridge made from maize, sorghum, or millet; the choice of cereal depending on preference and ethnicity. It is popular in Nigeria and in most West African countries, where it is mainly used for complementary feeding of infants, although it is also consumed by adults [7]. During fermentation, enzymes elaborated by the fermenting microorganisms break down many complex substances such as

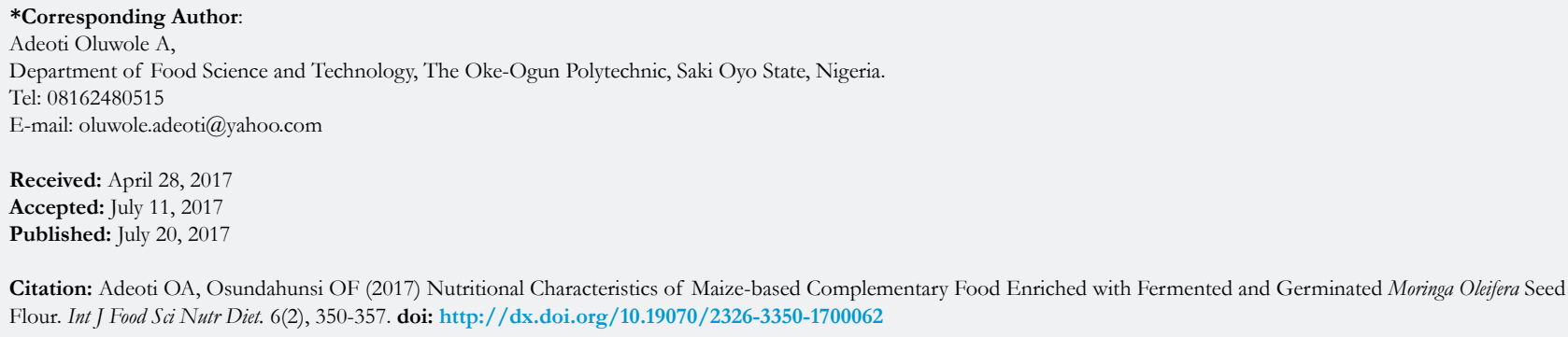

Copyright: Adeoti $\mathbf{O A}^{\circ}$ 2017. This is an open-access article distributed under the terms of the Creative Commons Attribution License, which permits unrestricted use, distribution and reproduction in any medium, provided the original author and source are credited. 
starch, oligosaccharides, protein and phytic acid complexes thus increasing the quantities and qualities of easily digestible nutrients in foods. This feature is a major benefit to the consumers of ogi, who are majorly infants, children and convalescent adults with weak digestive systems. Several attempts have been made to improve the nutritional status of ogi by fortification with proteinrich substrates such as soya beans, groundnuts, melon seeds and cowpea. Many authors have reported incorporation of fruits such as ripe dessert banana flour, baobab, pawpaw and breadfruit seeds $[3,5,16,50]$ among others have been incorporated into "ogi" for quality improvement. However, little information exists on the use of moringa oleifera seeds as a supplement to improve the nutritional status of "ogi".

Moringa oleifera is an underutilised plant and the whole seeds are highly restricted to eaten green, roasted or powdered and steamed in tea and curries $[24,48]$. The pods and seeds often referred to as Moringa kernels have a taste that ranges from sweet to bitter and are most popularly consumed after frying to get a groundnutlike taste. The seeds contain a profile of important minerals, and are good source of protein, vitamins, beta-carotene, amino acids and various phenolics compounds $[10,11]$. With these aforementioned nutritional profiles of the moringa seeds, there is the need to fully harness the potentials in moringa seeds which are highly available and relatively cheaper in Nigeria. Hence, this study has investigated the effect of fermented and germinated moringa oleifera seed flour on the nutritional quality improvement of ogi as complementary diet.

\section{Materials and Methods}

\section{Materials}

Moringa oleifera seeds were bought from Bashorun, a local market in Ibadan Oyo State and identified at the Department of Crop science, Federal University of Technology Akure, Nigeria while dried yellow maize grains used for the research were purchased from International Institute of Tropical Agriculture Ibadan, Nigeria.

\section{Methods}

Processing of raw moringa oleifera seed flour: Raw Moringa oleifera seeds were processed according to the method of Ijarotimi et al., (2013) with slight modification. The seeds were sorted, dehulled and oven dried at $50^{\circ} \mathrm{C}$ for $10 \mathrm{~h}$ in a cabinet drier (model QUB 30510G, Gallenkamp, U.K.). It was ground using a laboratory mill (Numex pep grinding mill, India) and sieved through $250 \mathrm{~mm}$ sieve to obtain raw moringa seed flour. The milled sample was packed in plastic container sealed with aluminum foil and stored in low density polyethylene bags under freezing condition $\left(-4^{\circ} \mathrm{C}\right)$ for subsequent analyses.

Processing of fermented Moringa oleifera seed flour: A modified method of Omafuvbe et al., (2004) [52] was used for the processing of fermented moringa seed flour. Moringa oleifera seeds was sorted, dehulled and boiled for $1 \mathrm{~h}$. The seeds thereafter were transferred into a pot, wrapped with blanched banana leaves and allowed to ferment at room temperature for $72 \mathrm{~h}$. The fermented seeds were oven dried at $50^{\circ} \mathrm{C}$ for $10 \mathrm{~h}$ in a cabinet drier. It was then ground using a laboratory mill, sieved through $250 \mathrm{~mm}$ sieve to obtain fermented moringa oleifera seed flour. The milled sample was packed in plastic container sealed with aluminum foil and stored in low density polyethylene bags under freezing condition $\left(-4^{\circ} \mathrm{C}\right)$ for subsequent analyses.

Processing of germinated Moringa oleifera seed flour: Moringa oleifera seeds were processed according to the method of Ijarotimi et al., (2013) with slight modification. The seeds were sorted and the seeds were soaked for $12 \mathrm{~h}$ in ten times of their volume of sterile distilled water to achieve hydration, following which the water was strained and the seeds were spread on perforated trays lined with wet cloth and covered with another wet cloth. The seeds were allowed to germinate (sprout) at room temperature $27 \pm 2{ }^{\circ} \mathrm{C}$ for a period of $72 \mathrm{~h}$. The germinated seeds were picked carefully with the sprouts, washed, dehulled, oven dried at $50^{\circ} \mathrm{C}$ for $10 \mathrm{~h}$ using cabinet drier and ground using a laboratory mill. It was then sieved through $250 \mathrm{~mm}$. The sieved sample was packed in plastic container sealed with aluminum foil and stored in low density polyethylene bags under freezing condition $\left(-4^{\circ} \mathrm{C}\right)$ for subsequent analyses.

Processing of maize "ogi' Alour: Yellow maize grains were weighed $(5 \mathrm{~kg})$ and sorted. It was soaked in hot water, and left for $72 \mathrm{~h}$. The grains were washed with distilled water; wet milled with an attrition mill (locally fabricated grinding machine), sieved with muslin cloth, and allowed to ferment for $72 \mathrm{~h}$. The fermented slurry was decanted, drained, oven dried in a cabinet drier at $50^{\circ} \mathrm{C}$ for 10 h, re-milled using a Philips laboratory blender (HR2811 model). It was then sieved through $250 \mathrm{~mm}$. The sieved sample was packed in plastic container sealed with aluminum foil and stored in low density polyethylene bags under freezing $\left(-4^{\circ} \mathrm{C}\right)$ for subsequent analyses.

Product formulation using material balance: In order to formulate weaning diet, the material balance method requires the use of proximate values of the raw materials and employs three basic categories; materials in, materials out and materials stored [8]. Therefore, the primary criteria is to select the components rich in providing protein and energy requirements while the next target is to know the proximate values of the raw materials that are going to be blended. They are required as an input for material balance. The compositions commonly used for product formulation are protein, carbohydrates, and fat that provides body with energy. The output components used in the material balance are from FAO/WHO standards based on the targeted age. Therefore, the material balance method was used to target $18 \%$ protein and $9 \%$ fat in the weaning blend formulation for particularly the age group of 6 to18 months [8].

The formulated products contained $66.60 \%$ and $33.40 \%$ for ogiraw moringa flour (ORM), $72.14 \%$ and $27.86 \%$ for fermented ogi-fermented moringa flour (OFM), $80.05 \%$ and $19.95 \%$ for ogi-germinated moringa (OGM) flour respectively.

\section{Analysis}

Determination of proximate composition and Energy value of the samples: Triplicate samples were analyzed for proximate composition, using standard official methods [12], while energy value was determined by using the Atwater's conversion factors. 
$1 \mathrm{kcal} / 100 \mathrm{~g}=[(4 \times$ carbohydrate $)+(4 \times$ protein $)+(9 \times$ fat $)]$

Determination of anti-nutritional factors: Phytates were determined by the anion-exchange method as described by method number 986.11 using phosphate as the standard. Oxalate content of the food samples was determined using the method of AOAC (2005) [12]. Tannin contents were determined by the modified vanillin- $\mathrm{HCl}$ methods described by (Nwinnuka et al., 2005) [47]. Trypsin activity of the samples was determined using the method of AOAC (2005) [12]. Saponin and alkaloid was determined using Spectrophotometric method as described by Ibrahim and Fagbohun,(2012) [30].

Determination of mineral composition: The method described by Association of Official Analytical Chemists (AOAC, 2005) [12] was used for mineral analysis. Two grams of each of the samples was digested with concentrated Nitric acid and Hydrogen peroxide, filtered and the filtrate in a $5 \mathrm{ml}$ volumetric flask was loaded to Atomic Absorption Spectrophotometer, (model 703 Perkin Elmes, Norwalk, CT, USA). Calcium, magnesium, iron, copper, zinc, sodium, potassium and iodine were determined at wavelengths $317.9 \mathrm{~nm}, 285.2 \mathrm{~nm}, 259.9 \mathrm{~nm}, 324.7 \mathrm{~nm}$, and $213.9 \mathrm{~nm}$ respectively. Phosphorus was determined using Vanodo-molybdate method. The serially diluted phosphate standard solution was made acidic by addition of $2 \mathrm{ml}$ nitric acid (2:1), 25 $\mathrm{ml}$ of the Vanodo-molybdate reagent was added, the solution was diluted to the mark with distilled water, mixed thoroughly and allowed to stand for $10 \mathrm{~min}$ and the optical density was measured at $470 \mathrm{~nm}$. All values were expressed in $\mathrm{mg} / 100 \mathrm{~g}$.

\section{Determination of functional properties:}

Determination of the bulk density: Bulk density was determined according to the method described by Maninder et al. , (2007) [45]. Each flour sample was gently filled into a $10 \mathrm{ml}$ graduated cylinder, previously tarred and the weight was recorded. The bottom of the measuring cylinder was gently tapped on a laboratory bench several times until there was no further decrease in the volume of the sample in the cylinder. Bulk (loose and tapped) densities were calculated as weight of sample per unit volume of sample $(\mathrm{g} / \mathrm{ml})$. Measurements were made in triplicate using the equation below:

Bulk density $=\left(\left(W_{1}-W_{2}\right) /(\right.$ Volume of sample before tapping $\left.)\right)$---- Eqn (1)

Where:

$\mathrm{W}_{1}=$ weight of sample before tapping

$\mathrm{W}_{2}=$ weight of sample after tapping

Determination of water and oil absorption capacities: The modified method of (Sefa-Dedeh et al., 2004) [60] was used to determine water and oil absorption capacities of the flour samples. About two gramme of each flour sample was weighed into $50 \mathrm{ml}$ preweighed centrifuge tubes and stirred into $40 \mathrm{ml}$ distilled water or refined soybean oil for $1 \mathrm{~h}$ on a shaker (Edmund Buhler SM 30). The mixtures were placed in a centrifuge (Spectra Scientific Merlin) and centrifuged at $2200 \mathrm{rpm}$ for $15 \mathrm{~min}$. The water or oil released on centrifugation was drained and the wet flour weighed to determine by difference the weight of bound water or oil. The percentage water absorption capacity ( $\%$ WAC) or oil absorption capacity $(\% \mathrm{OAC})$ was calculated using the following equation:

WAC or OAC $(\%)=(($ weight of bound water $) /($ weight of sample) $) \times 100$--- Eqn (2)

Determination of emulsion capacity: Emulsion capacity was determined by the method of (Oti and Akobundun, 2007) [56]. About one gramme of flour sample was mixed with $5 \mathrm{ml}$ of distilled water and equal volume $(5 \mathrm{ml})$ of refined groundnut oil and stirred. The mixture was centrifuged at high speed $2000 \mathrm{rpm}$ for $15 \mathrm{~min}$. The volume of oil separated from the sample after centrifuge was read directly from the tube. Emulsion capacity was expressed as the amount of oil emulsified and held per gramme of sample.

Determination of foaming capacity: The method of Jitngarmkusol et al., (2008) [39] was used for the determination of the foaming capacity of the samples with some slight modifications. About two gramme of each flour sample was mixed with $100 \mathrm{ml}$ of distilled water and the suspension was whipped with a kitchen blender. The whipped suspension was transferred into a $250 \mathrm{ml}$ graduated cylinder. Volumes of the whole mixture were recorded before and after whipping and the experiment was done in triplicate. The foaming capacity was calculated using the equation:

Foaming capacity $(\%)=\left(\left(\left(\mathrm{V}_{1}-\mathrm{V}_{2}\right) / \mathrm{V}_{\mathrm{I}}\right)\right) \times 100$---- Eqn (3)

Where:

$\mathrm{V}_{1}$ is the volume of initial mixture and $\mathrm{V}_{2}$ is the volume of the mixture after whipping and $V_{3}$ is the volume of the foam after 5 h.

Where $V_{1}$ is the volume of emulsion before centrifugation, $V_{2}$ is the volume of the emulsified layer.

Determination of solubility and swelling capacity: The solubility and swelling capacity (SC) of flour samples were determined using the method described by (Chatakonda et al., 2011) [19] with some modifications. Approximately 1 gramme of flour sample was weighed into a $50 \mathrm{ml}$ centrifuge tube containing $40 \mathrm{ml}$ deionized water and vortexed for $30 \mathrm{~min}$. The tubes were then heated in a thermostatically regulated water bath at $85^{\circ} \mathrm{C}$ for $20 \mathrm{~min}$ and cooled to room temperature. The tube and its contents were centrifuged at $2200 \mathrm{rpm}$ for $15 \mathrm{~min}$ and the clear supernatant carefully decanted into a preweighed petri dish. The weight of the residue/sediment was then noted. The water in the supernatant was evaporated and the difference in weight of petri dish was recorded as the weight of soluble fraction. Solubility and swelling power (SP) were calculated using the following equations:

Solubility $(\%)=(($ weight of soluble fraction $) /($ weight of sample $)) \times 100$ ---- Eqn (4)

Swelling Capacity $(\%)=(($ weight of sediment $) /$ weight of sample $\times$ $(100-$ solubility) $) \times 100$ Eqn (5)

Determination of least gelation concentration: Test tubes containing $20 \%(\mathrm{w} / \mathrm{v})$ dispersions of each diet were prepared with $5 \mathrm{ml}$ distilled water. The dispersions were heated for $1 \mathrm{~h}$ in a boiling water bath, cooled rapidly under running tap water 
and subsequently at $4^{\circ} \mathrm{C}$ for $2 \mathrm{~h}$. The test tubes were inverted to determine the concentration at which the sample would not slip.

Statistical design: Results were expressed as mean of triplicate analyses. A one-way analysis of variance and Duncan's test were used to establish the significance of differences among the mean values at the 0.05 significance level. The statistical analyses were performed using SPSS software version 21 (SPSS Inc., USA).

\section{Results}

\section{Proximate Composition (\%) and energy value (kcal/g) of} Ogi-moringa seed flour complementary diet

The proximate composition of the complementary diets is presented in Table 1 . The moisture content of the diets ranged between 4.72 and $8.75 \%$ for cerelac (control) and ogi-fermented moringa seed flour respectively. There was significant difference $(p<0.05)$ in the protein values of the samples with cerelac having the highest value $17.00 \%$ while ogi-raw moringa seed flour had the least value $15.27 \%$. The fat content ranged between 8.89 (cerelac) and 9.34\% (ogi-fermented moringa seed flour). The fibre and ash content of the samples ranged between 3.63 and $4.65 \%$ for (ogi-fermented moringa seed flour) and (cerelac), 2.27 and $2.99 \%$ respectively for (ogi-raw moringa seed flour) and (cerelac). The carbohydrate value of the diets ranged between 59.26 and $61.75 \%$ for (ogi-germinated moringa seed flour) and (cerelac). There was significant difference $(p<0.05)$ in the energy values of the diet. The values ranged between 386.28 for (ogi-fermented moringa seed flour) and $395.01 \mathrm{kcal} / \mathrm{g}$ for (cerelac) respectively.

\section{Antinutritional compositions of Ogi-moringa seed flour complementary diet}

The result of the antinutritional composition of the samples as presented in Table 2 show a significant difference $(p<0.05)$ in all the values of the parameters analysed. The phytate ranged between 0.09 for (cerelac) to $0.36 \mathrm{mg} / \mathrm{g}$ for (ogi-raw moringa seed flour) while the oxalate value of the complementary diet ranged between 0.06 for (cerelac) to $0.24 \mathrm{mg} / \mathrm{g}$ for (ogi-raw moringa seed flour). The tannin value ranged between 0.04 for (cerelac) and $0.26 \mathrm{mg} / \mathrm{g}$ for ((ogi-raw moringa seed flour). Other antinutritional compositions are saponin whose value ranged between 0.07 for (cerelac) and $0.46 \%$ for (ogi-raw moringa seed flour), alkaloid 0.07 and $0.28 \%$ and trypsin inhibitor 0.05 and $2.30 \mathrm{TIU} / \mathrm{mg}$ for (cerelac) and (ogi-raw moringa seed flour) respectively.

\section{Mineral compositions of Ogi-moringa seed flour comple- mentary diet (mg/100g)}

The mineral composition of the complementary diets is presented in Table 3. The compositions of the mineral shows that there was significant difference $(\mathrm{p}<0.05)$ among the samples. Sodium, potassium and calcium values ranged between 58.60 and 67.85 $\mathrm{mg} / 100 \mathrm{~g} ; 56.38$ and $66.79 \mathrm{mg} / 100 \mathrm{~g} ; 43.55$ and $59.66 \mathrm{mg} / 100 \mathrm{~g}$ for (ogi-raw moringa seed flour) and (cerelac) respectively. Other mineral elements include phosphorus, magnesium, copper, iron, iodine, manganese and zinc and the values ranged between 57.58 and $68.58 \mathrm{mg} / 100 \mathrm{~g} ; 53.00$ and $60.10 \mathrm{mg} / 100 \mathrm{~g} ; 12.46$ and 25.38 $\mathrm{mg} / 100 \mathrm{~g} ; 45.69$ and $67.36 \mathrm{mg} / 100 \mathrm{~g} ; 5.77$ and $11.35 \mathrm{mg} / 100 \mathrm{~g}$; 0.76 and $0.94 \mathrm{mg} / 100 \mathrm{~g} ; 14.57$ and $23.68 \mathrm{mg} / 100 \mathrm{~g}$. The $\mathrm{Na} / \mathrm{K}$ and $\mathrm{P} / \mathrm{Ca}$ ratios ranged between 0.96 and 0.98 and 1.15 and 1.32 respectively for (cerelac) and (ogi-raw moringa seed flour) sample.

\section{Functional properties of Ogi-moringa seed flour comple- mentary diets}

Functional property of the sample is presented in Table 4. The loosed and packed bulk densities of the diets ranged between 0.54 and $0.57 \mathrm{~g} / \mathrm{ml}$ for (cerelac) and (ogi-raw moringa seed flour) and 0.62 and $0.72 \mathrm{~g} / \mathrm{ml}$ for (ogi-fermented moringa seed flour) and (cerelac) respectively. Water absorption capacity, oil absorption capacity, emulsion capacity and foaming capacity values ranged from 179.00 and $194.00 \%$ for (ogi-fermented moringa seed flour) and (cerelac), 143.00 and $150.00 \%$ for (ogi-fermented moringa seed flour) and (cerelac), 25.87 and $33.60 \%$ for (ogi-fermented moringa seed flour) and (cerelac) and 16.79 and $22.10 \%$ for (ogifermented moringa seed flour) and (cerelac) respectively. Other functional properties of the diets are swelling capacity, least gelation concentration and solubility the values ranged between 20.79 and $29.68 \%, 6.26$ and $11.65 \%$ and 34.29 and $45.89 \mathrm{gm}^{-1}$ respectively.

\section{Discussion}

Low moisture content in complementary foods is very important to prevent nutrient losses and ensure adequate shelf life of the product as the removal of moisture generally increases concentrations of nutrients and make some nutrients more available [9]. The protein Advisory group of United Nation recommends that moisture content should not exceed $10 \%$ in order to keep a floury product for a reasonably long time $[51,58]$. The moisture content of the developed diets was higher than the values of 1.52 and $2.55 \%$ reported by Kumkum et al., (2010) [40] who developed weaning mixes containing roasted ingredients. The higher moisture content observed may be due to the processing techniques used (fermentation and germination). The protein content of the developed complementary foods is significantly lower than that of the cerelac (Control). However, the protein content of all the samples is within the range of $15 \%$ recommended by World Health Organisation (2001) [65] for complementary food. The protein content of the ogi-fermented moringa seed flour (OFM) and ogi-germinated moringa $(\mathrm{OGM})$ were significantly higher than ogi-raw moringa seed flour (ORM). Fasasi (2009) [25] reported that germination and fermentation improves the protein content and quality of food products. Increase in the protein content during germination and fermentation of the seeds may be attributed to the net synthesis of enzymic protein by the germinating and fermenting seeds [37]. The protein content is comparable to $16.00-20.00 \%$ reported by Lalude and Fashakin (2006) [41] that produced weaning foods from sorghum and oil seeds and $9.45-19.70 \%$ reported by Osundahunsi and Aworh (2002) [55] for various tempeh-fortified maize-based complementary diets. The fat content of the developed complementary food is significantly $(\mathrm{p}<0.05)$ higher than the control sample (cerelac), however, all the diets met the minimum requirement of $10-25 \%$ recommended by WHO (2001) for infant foods. All experimental crude fat values are in agreement with the values 4.8 and $9.42 \%$ reported by Ikujenlola and Fashakin (2005) [35] for complementary diets produced from quality protein maize-soy blends. Lalude and Fashakin (2006) [41] reported that the fat content of weaning food from sorghum and oil seeds was $9.21 \%$ which were in the 
Table 1. Proximate Composition (\%) and Energy (Kcal/g) of the Ogi-moringa Seed Flour Complementary Diets.

\begin{tabular}{|c|c|c|c|c|c|}
\hline Samples & ORM & OFM & OGM & CRL & *RDA \\
\hline Moisture & $8.65^{\mathrm{b}} \pm 0.04$ & $8.75^{\mathrm{a}} \pm 0.03$ & $8.46^{\mathrm{c}} \pm 0.03$ & $4.72^{\mathrm{d}} \pm 0.03$ & $<10$ \\
Crude protein & $15.27^{\mathrm{c}} \pm 0.11$ & $16.38^{\mathrm{b}} \pm 0.11$ & $16.58^{\mathrm{b}} \pm 0.10$ & $17.00^{\mathrm{a}} \pm 0.14$ & $>15$ \\
Crude fat & $9.20^{\mathrm{c}} \pm 0.03$ & $9.28^{\mathrm{b}} \pm 0.02$ & $9.34^{\mathrm{a}} \pm 0.03$ & $8.89^{\mathrm{d}} \pm 0.03$ & $10-25$ \\
Crude fibre & $3.76^{\mathrm{c}} \pm 0.02$ & $3.63^{\mathrm{d}} \pm 0.02$ & $3.87^{\mathrm{b}} \pm 0.02$ & $4.65^{\mathrm{a}} \pm 0.03$ & $<5$ \\
Ash & $2.27^{\mathrm{d}} \pm 0.02$ & $2.65^{\mathrm{b}} \pm 0.02$ & $2.49^{\mathrm{c}} \pm 0.04$ & $2.99^{\mathrm{a}} \pm 0.03$ & $<3$ \\
CHO & $60.85^{\mathrm{b}} \pm 0.13$ & $59.31^{\mathrm{c}} \pm 0.10$ & $59.26^{\mathrm{c}} \pm 0.07$ & $61.75^{\mathrm{a}} \pm 0.17$ & 64 \\
Energy & $387.28^{\mathrm{b}} \pm 0.31$ & $386.28^{\mathrm{d}} \pm 0.17$ & $387.42^{\mathrm{c}} \pm 0.13$ & $395.01^{\mathrm{a}} \pm 1.42$ & $380-425$ \\
\hline
\end{tabular}

Each value is a mean of triplicate determination. Values in the same row with different superscripts are significantly different $(\mathrm{p}<0.05)$. ORM- Ogiraw moringa seed flour; OFM- Ogi-fermented moringa seed flour; OGM- Ogi-germinated moringa seed flour; CRL- Cerelac (Control); *RDA-

(FAO/WHO, 2013).

Table 2. Anti-nutritional Compositions of Ogi-moringa Seed Flour Complementary Diets.

\begin{tabular}{|c|c|c|c|c|c|}
\hline Samples & ORM & OFM & OGM & CRL & *Critical values \\
\hline Phytate (mg/g) & $0.36^{\mathrm{a}} \pm 0.01$ & $0.29^{\mathrm{b}} \pm 0.00$ & $0.24^{\mathrm{c}} \pm 0.01$ & $0.09^{\mathrm{d}} \pm 0.00$ & $5-6 \mathrm{mg} / \mathrm{g}$ \\
Oxalate (mg/g) & $0.24^{\mathrm{a}} \pm 0.01$ & $0.23^{\mathrm{b}} \pm 0.02$ & $0.19 \mathrm{c} \pm 0.01$ & $0.06^{\mathrm{d}} \pm 0.01$ & $0.25 \mathrm{mg} / \mathrm{g}$ \\
Tannin (mg/g) & $0.26^{\mathrm{a}} \pm 0.01$ & $0.21^{\mathrm{b}} \pm 0.01$ & $0.15^{\mathrm{c}} \pm 0.01$ & $0.04^{\mathrm{d}} \pm 0.00$ & $3 \mathrm{mg} / \mathrm{g}$ \\
Saponin (\%) & $0.46^{\mathrm{a}} \pm 0.01$ & $0.38^{\mathrm{b}} \pm 0.01$ & $0.35^{\mathrm{c}} \pm 0.01$ & $0.07^{\mathrm{d}} \pm 0.00$ & - \\
Alkaloid (\%) & $0.28^{\mathrm{a}} \pm 0.01$ & $0.26^{\mathrm{b}} \pm 0.01$ & $0.23^{\mathrm{c}} \pm 0.01$ & $0.07^{\mathrm{d}} \pm 0.00$ & - \\
TIA (TIU/Mg) & $2.30^{\mathrm{a}} \pm 0.02$ & $2.11^{\mathrm{b}} \pm 0.01$ & $1.86^{\mathrm{c}} \pm 0.02$ & $0.05^{\mathrm{d}} \pm 0.00$ & 0.25 \\
\hline
\end{tabular}

Each value is a mean of triplicate determination. Values in the same row with different superscripts are significantly different $(\mathrm{p}<0.05)$. ORM- Ogiraw moringa seed flour; OFM- Ogi-fermented moringa seed flour; OGM- Ogi-germinated moringa seed flour; CRL- Cerelac (Control).

Table 3. Mineral (mg/100g) Compositions of Ogi-moringa Seed Flour Complementary Diets.

\begin{tabular}{|c|c|c|c|c|}
\hline Samples & \multicolumn{1}{|c|}{ ORM } & \multicolumn{1}{c|}{ OFM } & OGM & CRL \\
\hline Sodium & $58.60^{\mathrm{c}} \pm 0.01$ & $69.75^{\mathrm{b}} \pm 0.01$ & $69.99^{\mathrm{b}} \pm 0.01$ & $77.85^{\mathrm{a}} \pm 0.01$ \\
Potassium & $56.38^{\mathrm{d}} \pm 0.01$ & $67.42^{\mathrm{c}} \pm 0.01$ & $68.47^{\mathrm{b}} \pm 0.01$ & $76.79^{\mathrm{a}} \pm 0.01$ \\
Calcium & $43.55^{\mathrm{d}} \pm 0.01$ & $65.67^{\mathrm{c}} \pm 0.01$ & $68.11^{\mathrm{b}} \pm 0.01$ & $69.66^{\mathrm{a}} \pm 0.01$ \\
Phosphorus & $50.00^{\mathrm{d}} \pm 0.17$ & $79.11^{\mathrm{c}} \pm 0.01$ & $73.44^{\mathrm{b}} \pm 0.01$ & $78.58^{\mathrm{a}} \pm 0.01$ \\
Magnessium & $53.00^{\mathrm{b}} \pm 0.01$ & $54.11^{\mathrm{b}} \pm 0.01$ & $54.11^{\mathrm{b}} \pm 0.01$ & $60.10^{\mathrm{a}} \pm 0.01$ \\
Copper & $12.46^{\mathrm{d}} \pm 0.01$ & $15.28^{\mathrm{c}} \pm 0.01$ & $16.38^{\mathrm{b}} \pm 0.01$ & $25.38^{\mathrm{a}} \pm 0.01$ \\
Iron & $45.69^{\mathrm{d}} \pm 0.01$ & $47.15^{\mathrm{c}} \pm 0.01$ & $48.24^{\mathrm{b}} \pm 0.01$ & $67.36^{\mathrm{a}} \pm 0.01$ \\
Iodine & $5.77^{\mathrm{d}} \pm 0.01$ & $7.22^{\mathrm{c}} \pm 0.01$ & $7.93^{\mathrm{b}} \pm 0.01$ & $11.35^{\mathrm{a}} \pm 0.01$ \\
Manganese & $0.76^{\mathrm{d}} \pm 0.01$ & $0.79^{\mathrm{c}} \pm 0.01$ & $0.80^{\mathrm{b}} \pm 0.01$ & $0.94^{\mathrm{a}} \pm 0.01$ \\
Zinc & $14.57^{\mathrm{d}} \pm 0.01$ & $15.13^{\mathrm{c}} \pm 0.01$ & $16.19^{\mathrm{b}} \pm 0.01$ & $23.68^{\mathrm{a}} \pm 0.01$ \\
K/Na & $0.96^{\mathrm{b}} \pm 0.01$ & $0.97^{\mathrm{b}} \pm 0.01$ & $0.97^{\mathrm{b}} \pm 0.01$ & $0.99^{\mathrm{a}} \pm 0.01$ \\
P/Ca & $1.15^{\mathrm{b}} \pm 0.01$ & $1.20^{\mathrm{c}} \pm 0.01$ & $1.07^{\mathrm{a}} \pm 0.01$ & $1.12^{\mathrm{d}} \pm 0.01$ \\
\hline
\end{tabular}

Each value is a mean of triplicate determination. Values in the same row with different superscripst are significantly different $(\mathrm{p}<0.05)$. ORM- Ogiraw moringa seed flour; OFM- Ogi-fermented moringa seed flour; OGM- Ogi-germinated moringa seed flour; CRL- Cerelac (Control).

same range with the value obtained in this study. Although, high fat content is nutritionally advantageous because it can increase the energy level of a diet, however, it can reduce the shelf life and stability of the food product during storage since unsaturated oils are vulnerable to oxidative rancidity [2]. The fibre content of the developed samples was less than the recommended value of less than $5 \%$ specified by the FSSAI (2011) [28]. Weaning food with low fibre content is very important as this would enable children to consume food that is more nutrient-dense and to meet the daily energy and other vital nutrient requirements [31]. Emphasis is placed on the importance of low fibre in weaning food because the gastrointestinal system of the infants may not be well developed to handle diet high in fibre content as this has been reported to impair protein and mineral digestion and absorption in human subjects [14]. The level of ash in food is an important nutritional indicator of minerals density and also a quality parameter for contamination [42]. The ash content of the control sample (cerelac) was significantly higher, however, among the formulated diets the ash content of the ogi-fermented moringa seed flour and ogigerminated moringa seed flour were higher than the ogi-raw moringa seed flour diet and this could be as a result of improved bioavailability of minerals during fermentation and germination. The carbohydrate content of the developed samples is in agreement with the values reported in germinated weaning formulations using millet (60.2-69.6\%) by Imitaz, et al., (2011) [36]. Carbohydrate contributes to the bulk of energy of the sample which makes it 
Table 4. Functional Properties of Ogi-moringa Seed Flour Complementary Diets.

\begin{tabular}{|c|c|c|c|c|}
\hline Samples & ORM & OFM & OGM & CRL \\
\hline LBD $(g / m l)$ & $0.57^{\mathrm{a}} \pm 0.01$ & $0.56^{\mathrm{a}} \pm 0.01$ & $0.56^{\mathrm{a}} \pm 0.01$ & $0.54^{\mathrm{b}} \pm 0.01$ \\
PBD g/ml) & $0.69^{\mathrm{b}} \pm 0.01$ & $0.62^{\mathrm{b}} \pm 0.01$ & $0.62^{\mathrm{b}} \pm 0.01$ & $0.72^{\mathrm{a}} \pm 0.01$ \\
WAC (\%) & $186.00^{\mathrm{b}} \pm 0.58$ & $179.00^{\mathrm{d}} \pm 0.58$ & $182.00^{\mathrm{c}} \pm 0.58$ & $194.00^{\mathrm{a}} \pm 0.58$ \\
OAC (\%) & $140.00^{\mathrm{d}} \pm 0.58$ & $143.00^{\mathrm{c}} \pm 0.58$ & $147.00^{\mathrm{b}} \pm 0.58$ & $150.00^{\mathrm{a}} \pm 0.58$ \\
EC (\%) & $27.94^{\mathrm{b}} \pm 0.01$ & $25.87^{\mathrm{d}} \pm 0.01$ & $26.50^{\mathrm{c}} \pm 0.01$ & $33.60^{\mathrm{a}} \pm 0.01$ \\
FC (\%) & $18.48^{\mathrm{b}} \pm 0.01$ & $16.79^{\mathrm{d}} \pm 0.01$ & $17.24^{\mathrm{c}} \pm 0.01$ & $22.10^{\mathrm{a}} \pm 0.01$ \\
SC (\%) & $22.69^{\mathrm{b}} \pm 0.04$ & $20.79^{\mathrm{d}} \pm 0.01$ & $21.47^{\mathrm{c}} \pm 0.01$ & $29.68^{\mathrm{a}} \pm 0.01$ \\
LGC (\%) & $8.94^{\mathrm{b}} \pm 0.01$ & $6.26^{\mathrm{d}} \pm 0.01$ & $7.59^{\mathrm{c}} \pm 0.01$ & $11.65^{\mathrm{a}} \pm 0.01$ \\
Solubility gm & $34.29^{\mathrm{d}} \pm 0.01$ & $36.80^{\mathrm{b}} \pm 0.01$ & $35.68^{\mathrm{c}} \pm 0.01$ & $45.89^{\mathrm{a}} \pm 0.01$ \\
\hline
\end{tabular}

Each value is a mean of triplicate determination. Values in the same row with different superscripts are significantly different ( $<<0.05)$. ORM- Ogiraw moringa seed flour; OFM- Ogi-fermented moringa seed flour; OGM- Ogi-germinated moringa seed flour; CRL- Cerelac (Control).

LBD- Loosed bulk density, PBD- Packed bulk density, WAC- Water absorption capacity, OAC-Oil absorption capacity, EC- Emulsion capacity, FCFoaming capacity, SC- Swelling capacity, LGC- Least gelation concentration.

high energy food and ideal for the growth of growing infants [6]. The calories in an infant diet are provided by the protein, fat and carbohydrate which are major components of complementary foods that help to meet the energy requirement of growing infants and lack of any of these may lead to malnutrition [14]. The calorie value of the developed and control samples are within specific minimum requirement of $380-425 \mathrm{kcal}$ as recommended by FAO (2004) [29]. The calorie value of formulated diets is also within the range of $372-397 \mathrm{kcal} / 100 \mathrm{~g}$ reported for complementary diets based on cereal and legumes combination [18]. Tizazu et al., (2010) [63] also reported energy values of weaning blends prepared from sorghum, legumes and oilseeds as 405.8 to 413.2 $\mathrm{Kcal} / 100 \mathrm{~g}$ which is higher than the values obtained in this study. The result of the antinutritional composition of the developed complementary diets that is the ogi-fermented seed flour and ogigerminated moringa seed flour were found to be significantly reduced $(\mathrm{p}<0.05)$ compared with that of ogi-raw moringa seed flour. The control (cerelac) sample has the least phytate content while the ogi-raw moringa flour (ORM) had the highest value. These results are in agreement with Abdelhalem et al., (2008) and Makokha et al., (2002) [1, 43] who reported that fermentation and germination of sorghum in the production of complementary foods produces a significant reduction in phytate concentration. Fagbemi et al., (2005) [27] also reported that fermentation is the most effective processing method that reduced phytic acid in cereal flour and the reduction may be attributed to the secretion of the enzyme phytase during fermentation. Suna and Uroo (2014) [61] also reported that during cooking, phytic acid may decrease due to the formation of insoluble complexes between phytate and other content at high temperature. There was significant decrease in the oxalate value of the sample and this showed that the oxalate content of the sample including the control (cerelac) sample is within the tolerable level. Oxalate forms complexes with calcium, magnesium and iron leading to the formation of insoluble salts. High concentration of oxalate in the diets can increase the risk of kidney calcium absorption, which resulted in kidney stone and oxalate poisoning [21]. The trypsin inhibitor activity (TIA) observed was significantly reduced due to the processing methods used. Protease inhibitors such as trypsin inhibitor in diets lead to formation of irreversible trypsin-enzyme inhibitor complexes. This causes a decrease in trypsin in the intestine and subsequently indigestibility of dietary protein, thus leading to slower growth in children [59]. There was a significant difference $(p<0.05)$ in the mineral elements composition of the formulated and control diets. The results showed that the mineral composition of the control sample (cerelac) was the highest. The mineral content of ogifermented and ogi-germinated moringa oleifera seed complementary diets were significantly higher than the ogi-raw moringa seed flour complementary diet and this increment in mineral content of the diets may be due to the processes of fermentation and germination as reported by Ikujenlola (2008) [34]. The ratios of potassium to sodium $(\mathrm{Na} / \mathrm{K})$ and phosphorus to calcium $(\mathrm{P} / \mathrm{Ca})$ are indices of body electrolyte balance and bone formation respectively. $\mathrm{K}: \mathrm{Na}$ less than one is recommended in the diet of infant, therefore the complementary diets formulated in this present study is comparable to recommended ratio. The high $\mathrm{P} / \mathrm{Ca}$ ratio observed in this study is of great nutritional benefits particularly for children and aged that needs higher intake of calcium and phosphorus for bone formation and maintenance. Study has shown that food is considered good if the $\mathrm{P} / \mathrm{Ca}$ ratio is above one and poor if the ratio is less than 0.5 [46]. Bulk density is defined as the ratio of flour weight to the volume in gram per millitre. It is a measure of flour heaviness and an important parameter that determines the suitability of flour for the ease particulate food packaging and transportation [4]. High bulk density is a disadvantage in case of ready-to-use complementary food (RUCF) because it can limit the nutrient intake per feed [38]. The lower loose bulk density implies that less quantity of the food samples would be packaged in constant volume thereby ensuring an economical packaging. Nutritionally, low loose bulk density promotes easy digestibility of food products, particularly among children with immature digestive system [55]. The bulk density of ogi-fermented moringa (OFM) and ogi-germinated moringa (OGM) were lower than the ogi-raw moringa samples. Both fermentation and germination have been shown to reduce bulk density [33]. The decrease in the bulk density after fermentation and germination would be advantageous in the preparation of infant gruels because high bulk density limits the caloric and nutrient intake per feed per child and infant sometimes are unable to consume enough to satisfy their energy and nutrient requirement [53]. The value of the bulk density (both loosed and packed) is in agreement with the value of 0.54-0.71 g/ml reported by Lalude and Fashakin (2006) [41] of a weaning food from sorghum, oilseeds and Nutrend. However, these values are higher than those reported by Cuevas-Rodriquez et al., (2006) [20] with the value of $0.50-0.54 \mathrm{~g} / \mathrm{ml}$ for nutritional quality of tempeh flour. Water absorption capacity was also re- 
duced by both fermentation and germination. Lower water absorption capacity is desirable for making gruels in which more flour can be added per unit volume of the gruel as this will help to increase the energy density and nutrient content of infant food. Oil absorption capacity is an important functional property as it is attributed to the physical entrapment of oil which is considered important as flour retainer and improves the mouth feel of food products [57]. From statistical analysis, there was significant difference $\mathrm{p}<0.05$ in the oil absorption capacity. It was observed that oil absorption capacity of ogi-fermented moringa seed flour and ogi-germinated moringa seed samples were higher than ogiraw moringa seed flour. Imitiaz et al., (2011) [36] reported that germination of seeds enhances the oil absorption capacity due to the entrapment of oil related to the non-polar side chain of the protein. Flour from seeds and legumes that had oil absorption capacity of more than $6.00 \%$ have been reported to perform well in the formulation of meat extenders, bakery and weaning products $[57,66]$. Swelling capacity of food gives an indication of increase in the volume upon absorption of water. It is very important parameter when changes in volume after processing enhance the acceptability of the final product. There was a significant difference $(p<0.05)$ in the swelling capacity of the samples. It was observed that the swelling capacity of ogi-fermented moringa seed flour and ogi-germinated moringa seed flour were significantly reduced. The observed decrease may be as a result of disruption of hydrogen atom inherent in the seed by amylases and proteases into sugars and amino acids as reported by Egwim and Ademonom (2009) [23]. A flour product with high swelling capacity has comparative advantages over those with low swelling capacity as the volume of the final product with high swelling capacity is of economic advantage [54]. The least gelation concentrations of ogi-fermented moringa seed flour and ogi-germinated moringa seed flour were lower than the control sample (cerelac). Least gelation concentration is an index of gelation. According to Olapade and Adetuyi (2007) [50] gels are characterized by their viscosity, plasticity and elasticity and the higher the least gelation concentration, the lower is the ability of the flour to form a stable gel. From the present study, it was found that ogi-fermented moringa seed flour and ogi-germinated moringa seed flour formed a stable gel than ogi-raw germinated moringa seed flour and cerelac and such product will serves as a good binder and provide consistency in food preparation such as semi-solid beverages like kunun-zaki [24]. However, high least gelation concentration observed in ogi-raw moringa seed flour and cerelac samples are desirable as Arawande and Borokini (2010) [13] reported that high least gelation concentration will lead to reduction in viscosity which therefore leads to increase in nutrient density and low dietary bulk which is highly favorable for a good weaning diets.

\section{Conclusion}

Ogi-based complementary diets were formulated with fermented or germinated Moringa oleifera seed flour. The ogi-fermented moringa oleifera seed flour complementary diet is more nutritious in terms of the nutrient and also shown to have good functional properties as weaning food. The finding from this research work has increased the utilisation of the fermented Moringa oleifera seed which still remain underutilised in developing countries, resulting in its usage as complementary diets for the low income family instead of over-dependant on available but costly Nigerian com- mercial weaning foods.

\section{References}

[1]. Abdelhaleem WH, El Tinay AH, Mustafa AI, Babiker EE (2008) Effect of fermentation, malt-pretreatment and cooking on antinutritional factors and protein digestibility of sorghum cultivars. Pakistan J Nutrition. 7(2): 335341.

[2]. Adebayo AO, Olatodoye OP, Ogundipe OO, Akande E, Isiah CG (2012) Production and quality evaluation of complementary foods formulated from fermented sorghum, walnut and ginger. J Appl Biosci. 54: 3901-3910.

[3]. Adejuyitan JA, Abioye AO, Otunola ET, Oyewole YN (2012) An Evaluation of Some Properties of Baobab Fruit Powder and Ogi Mixes. Transnational J Sci Technol. 2(7): 99-102.

[4]. Adejuyitan, JA, Otunola ET, Akande EA, Bolarinwa IF, Oladokun FM (2009) Some physicochemical properties of flour obtained from fermentation of tigernuts (Cyperus esculentus) sourced from a market in Ogbomoso, Nigeria. Afr J Food Sci. 3(2): 51-55.

[5]. Adeyemi IA, Soluade EO (1993) Development and Quality Evaluation of Pawpaw-Ogi. Plant Foods Human Nutri. 44(3): 213-220.

[6]. Agu HO, Aluyah E (2004) Production and chemical analysis of weaning food from maize, soybean and fluted pumpkin seed flour. Nigeria Food J. 22(1): 171-177.

[7]. Ajanaku KO, Oguniran OO, Ajani OO, James OC, Nwinyi O (2010) Improvement of nutritive value of sorghum "ogi" fortified with pawpaw (Carica papaya L) fruit. Cereal Sci Biotechnol. 4(1): 98:101.

[8]. Amankwa EA, Barimah J, Nuamah AKM., Oldham JH, Nnaji CO (2009) Formulation of weaning food from fermented maize, rice, soybean and fish meal. Pakistan J Nutri. 8 (11): 1747-1752.

[9]. Amankwah EA, Barimah J, Acheampong R, Addai LO, Nnaji CO (2009) Effect of Fermentation and Malting on the Viscosity of Maize-Soyabean weaning blends. Pakistan J Nutr. 8(10): 1671-1675.

[10]. Anjorin TS, P Ikokoh, S Okolo (2010) Mineral composition of Moringa oleifera leaves, pods and seeds from two regions in Abuja, Nigeria. Int J Agri Biol. 12: 431-434.

[11]. Anwa, F, Rashid S (2007) Moringa oleifera: A Food plant with multiple medicinal uses. Phytother Res. 2(1): 17-25.

[12]. Association of Official Methods of Analysis Analytical Chemists (2005) official methods of analysis (18th edn), AOAC, Gaithersburg, MD USA.

[13]. Arawande JO, Borokini FB (2010) Comparative study on chemical composition and functional properties of three Nigerian legumes (Jack beans, pigeon pea and cowpea). J Emerging Trends in Engineering Applied Sciences (JETEAS). 1(1): 89-95.

[14]. Asma MA, Fadil EBE, Tinay AHE (2006) Development of weaning food from sorghum supplemented with legumes and oil seeds. Food Nutr Bull. 27(1): 26-34.

[15]. Ayo JA, Oluwalana IB, Idowu MA, Ikuomola DS, Ayo VA, et al., (2011) Production and evaluation of millet-egg-soybean hull composite flour: A weaning food. Am J Food Nutr. 1(1): 7-13.

[16]. Ayo-Omogie HN, Adeyemi IA, Otunola ET (2010) "Effect of Ripening on Some Physicochemical Properties of Cooking Banana (Musa ABB Cardaba) Pulp and Flour". Intl J Food Sci Technol. 45(12): 2605-2611.

[17]. Balasubramanian S, Kaur J, Singh D (2014) Optimization of weaning mix based on malted and extruded pearl millet and barley. J Food Sci Technol. 51(1): 682-690.

[18]. Baskaran V, Bhattacharaya S (2004) Nutritional status of the protein of corn-soy based extruded products evaluated by rat bioassay. Plant Foods Hum Nutr. 59(3): 101-104.

[19]. Chatakonda P, Wansukri R, Sriroth K (2011) Impact of annealing on susceptibility to acid hydrolysis and physicochemical properties of cassava starch. Kasetsart J (Nat Sci). 45: 284-294.

[20]. Cuevas-Rodrı'guez EO, Verdugo-Montoya NM, Angulo-Bejarano PI, Mila' n-Carrillo J, Mora-Escobedo R, et al., (2006) Nutritional properties of tempeh flour from quality protein maize (Zea mays L.). LWT. 39(10): 1072-1079.

[21]. Davidsson L, Ziegler EE, Kastanmayer P, VanDael P, Barclay D (2004) Dephytinization of soy isolate with low phytic acid content has limited impact on mineral and trace elements absorption in healthy infants. $\mathrm{Br} \mathrm{J}$ Nutr. 91(2): 287-93.

[22]. Edema MO, Sanni LO, Sanni AI (2005) Evaluation of maize-soybean flour blends for sour maize bread production in Nigeria. Afr J Biotechnol. 4(9): 911-918.

[23]. Egwin E, Adenomon M (2009) Predicting $\alpha$-amylase yield and malt quality of some sprouting cereals using 2 nd order polynomial model. Afr J Biochem Res. 3(8): 288-292.

[24]. Fahey JW (2005) Moringa oleifera: A review of the medical evidence for its 
nutritional, Therapeutic and prophylactic properties Part 1. Tree for Life J. 1(5): 1-19.

[25]. Fasasi OS, Adeyemi OA, Fagbenro OA (2007) Functional and pasting characteristic of fermented maize and Nile tilapia (Oreochromis niloticus) flour diet. Pakistan J Nutr. 6(4): 304-309.

[26]. Fasasi OS (2009) Proximate, Antinutritional factors and functional properties of processed pearl millet (Pennisetum glaucum). J Food Technol. 73(3): 92-97.

[27]. Fagbemi TN, Oshodi AA, Ipinmoroti KO (2005) Processing effects on some antinutritional factors and in vitro multienzyme protein digestibility (IVPD) of three tropical seeds: Breadnut (Artocarpusaltilis), cashewnut (Anacardium occidentale) and fluted pumpkin (Telfairiaoccidentalis). Pakistan J Nutr. 4(4): $250-256$

[28]. Food Safety and Standards Authority of India (2011) The food safety standards (Food products standards and food additives) regulations. New Delhi commercial Law publishing, India.

[29]. FAO (2004) Under nourishment around the World. The state of food insecurity in the World Rome. 1-9.

[30]. Ibrahim TA, Fagbohun ED (2012) Phytochemical and Nutritive Quality of Dried Seeds of Buchholzia Coriacea. Greener J Physical Scie. 2(5): 185-191.

[31]. Ijarotimi S, Keshiro OO (2013) Determination of nutrient composition and protein quality of potential complementary foods formulated from combination of fermented popcorn, African locust bean and bambara groundnut seed flour. Pol J Food Nutr Sci. 63(3): 155-166.

[32]. Ijarotimi Oluwole S, Adeoti Oluwole A, Ariyo Oluwaseun (2013) Comparative study on nutrient composition, phytochemical, and functional characteristics of raw, germinated, and fermented Moringa oleifera seed flour. Food Sci Nutri. 1(6): 452-463.

[33]. Ikujenlola AV, Adurotoye EA (2014) Evaluation and quality characteristics of high nutrient dense complementary food from mixtures of malted quality protein maize (Zea mays. L) and steamed cowpea (Vigna unguiculata). J Food Process Technol. 5: 291

[34]. Ikujenlola AV (2008) Chemical and functional properties of complementary food from malted and unmalted Acha (Digitaria exilis), soybean (Glycine max) and defatted sesame seed (Sesamun indicuml). J Eng Appl Sci. 3(6): 471-475.

[35]. Ikujenlola AV, Fashakin JB (2005) The Physico-chemical properties of a complementary diet from vegetable proteins. J Food, Agricult Environ. 3(3): 23-26.

[36]. Imitiaz H, Burhanuddin M, Gulzar M (2011) Evaluation of weaning foods formulated from germinated wheat and mungbean from Bangladesh. Afr J Food Sci. 5(7): 897-903.

[37]. Inyang CU, Zakari KK (2008) Effect of germination and fermentation of pearl millet on the proximate, chemical and sensory properties of instant "Fura" a Nigerian cereal food. Pakistan J Nutr. 7(1): 9-12.

[38]. Isah AP, Danladi Y, Ejike OJ (2013) Proximate composition and some functional properties of flour from the kernel of African star apple (Chrysophyllual albidum). Int J Agricult Policy Res. 1(3): 062-066.

[39]. Jitngarmkusol S, Hongsuwankul J, Tananuwong K (2008) Chemical compositions, functional properties and microstructure of defatted macadamia flours. Food Chem. 110(1): 23-30.

[40]. Kumkum R, Gowda C, Khanam A, Swamylingappa B (2010) Chemical, functional and nutritional characteristic of weaning food formulations. J Food Sci Technol. 6: 36-42.

[41]. Lalude LO, Fashakin JB (2006) Development and Nutritional Assessment of a Weaning Food from Sorghum and Oil-Seeds. Pakistan J Nutr. 5(3): 257-260.

[42]. Lee YR, Kim JY, Woo KS, Hwang IG, Kim KH, et al., (2007) Changes in the chemical and functional components of Korean rough rice before and after germination. Food Sci Biotechnol. 16(6): 1006-1010.

[43]. Makokha AO, Oniang'o RK, Njoroge SM, Kinyanjui PK (2002) Effect of traditional fermentation and malting on phytic acid and mineral availability from sorghum (Sorghum bicolor) and finger millet (Eleusine coracana) grain varieties grown in Kenya. Afr J Food Nutr Sci. 2(2): 20-24.

[44]. Magda SM, Dalia ME (2013) Nutrtional Evaluation of Weaning Food Blends Fortified with Some Carotenoids- Rich Vegetables. J Appl Sci Res. 9(3): 1573-1582.

[45]. Maninder K, Kawaljit SS, Narpinder S (2007) Comparative study of the functional, thermal and pasting properties of flours from different field pea (Pisum sativum L.) and pigeon pea (Cajanus cajan L.) cultivars. Food Chem- istry. 104(1): $259-267$.

[46]. Nieman DG, Butterworth DE, Nieman CN (1992) Nutrition. Winc Brow Publishers, Dubugne, USA. 237-312.

[47]. Nwinnuka NM, Ibeh GO, Ekeke GI (2005) Proximate composition and levels of some toxicants in four commonly consumed spices. J Appl Sci Environ Manage. 9(1): 150-155.

[48]. Ogbe AO, Affiku JP (2011) Proximate study, mineral and anti-nutrient composition of moringaoleifera leaves harvested from Lafia, Nigeria: potential benefits in poultry nutrition and health. J Microbiol Biotechnol Food Sci. 1(3): 296-308

[49]. Okorie SU, Ehirim F, Umelo C, Ihemeje A, Ekwe CC (2013) Evaluation of quality characteristics of composite diets prepared from sprouted and fermented millet and breadfruit Seed Flours. Global Advanced Res J Agricult Sci. 2(4): 109-115.

[50]. Olapade AA, Adetuyi DO (2007) Comparison of different methods of producing bambara (V. Subterranean L. Thou) flours for preparation of moin moin. Nigerian Food J. 25(2): 150-157.

[51]. Olorunfemi OB, Akinyosoye FA, Adetuyi FC (2006) Microbial and nutritional evaluation of infant weaning food from mixture of fermented food substrates. Res J Biol Sci. 1(1-4): 20-23.

[52]. Omafuvbe BO, Falade OS, Bolanle A, Osuntogun BA, Adewusi SR (2004) Chemical and biochemical changes in African locust bean (Parkia biglobosa) and melon (Citrullus vulgaris) seeds during fermentation to condiments. Pakistan J Nutr. 3(3): 140-145.

[53]. Omueti O, Otegbayo B, Jaiyeola O, Afolabi O (2009) Functional properties of complementary diets developed from soybean (Glycine max), groundnut (Arachis hypogea) and crayfish (Macrobrachium spp). J Environ Agricult Food Chemi. 8(8): 563-573

[54]. Onigbogi IO, Adesina A (2006) Functional properties of cowpea/soybean flour blends for akara processing. Proceedings of the 30th Annual conference/general meeting of Nigeria Institute of Food Science and Technology, Lagos. 77-78.

[55]. Osundahunsi O, Aworh OC (2002) A preliminary study on the use of tempe-based formula as weaning diets in Nigeria. Plant Food Human Nutr. 57(3-4): 365-37.

[56]. Oti E, Akobundu ENT (2007) Physical, Functional and amylograph pasting properties of cocoyam-soybean-crayfish flour blends. Nigeria Food J. 25(1): 161-170.

[57]. Oyebode ET, Ojo MA, Oshodi AA (2007) Physicochemical properties and in-vitro protein digestibility of flour and protein isolates from Adenopus breviflorus Benth seed. Science Focus. 12(1): 28-34.

[58]. PAG (1971) Guideline no. 8: Protein rich mixtures for use as weaning foods. FAO/ WHO/UNICEF, New York, USA. 1-7.

[59]. Pugalentin, M, Vadival V, Siddhuraju P (2005) Alternative food/feed perspective of underutilized legume mucuna pruriens var. utili- A review. Plant Food for Hum Nutr. 60(4): 201-218.

[60]. Sefa-Dedeh S, Cornelius B, Sakyi-Dawson E, Afoakwa EO (2004) Effect of Nixtamalization on the chemical and functional properties of maize. Food Chem. 86(3): 317-324.

[61]. Suna PF, Uroo A (2014) Antioxidant activity in two pearl millet (Pennisetu typhoidenum) cultivars as influenced by processing. Antioxidants. 3(1): 5556.

[62]. Temesgen M (2013) Nutritional status of Ethiopian weaning and complementary foods: A review. Scientific Report. 2: 1-9.

[63]. Tizazu SK, Urga C, Abuye P, Retta N (2010) Improvement of energy and nutrient density of sorghum based complementary foods using germination. African Journal of Food Agricult Nutr Develop. 10(8): 1684-5358.

[64]. Wakil SM, Kazeem MO (2012) Quality assessment of complementaryf ood produced from fermented cereal-legume blends using starters. Int Food Res J. 19(4): 1679-1685

[65]. WHO (2001) Guiding principles for complementary feeding of the breastfed child. Pan American Health Organization, Washington DC.

[66]. Yadahally NS, Vadakkot BS, Vishwas MP (2008) Expansion properties and ultrastructure of legumes: effects of chemical and enzyme pre-treatments. Food Sci Technol. 42(1): 44-49. 